\title{
PERTANGGUNGJAWABAN PIDANA KORPORASI DALAM UNDANG-UNDANG BADAN PENYELENGGARAAN JAMINAN SOSIAL (BPJS)
}

\author{
Asmaun Zuhub ${ }^{1}$, Handyka Prayogi Lesmana ${ }^{2}$ \\ 1. Karyawan Kantor Hukum \\ 2. Dosen Program Studi Ilmu Hukum, Fakultas Hukum, Universitas Gresik
}

\begin{abstract}
ABSTRAK
Karyawan yang seharusnya dilindungi dan diberikan jaminan sosial seringkali hak-haknya tidak terpenuhi oleh korporasi namun karyawan tetap harus bekerja tanpa ada perlindungan hukum oleh korporasi. Penelitian ini bertujuan mengetahui bentuk pertanggungjawaban pidana korporasi dalam undang undang BPJS dan mekanisme penerapan sanksi dalam undang undang BPJS. Penelitian ini menggunakan metode penelitian hukum normatif dengan meneliti peraturan perundangan khususnya UUBPJS dan bahan pustaka lain terkait permasalahan bpjs. Hasil penelitian menunjukkan bahwa Undang-Undang Nomor 24 Tahun 2011 tentang Badan Penyelenggaraan Jaminan Sosial tidak mengatur mengenai pertanggungjawaban pidana korporasi dalam urusan kewajiban kepesertaan namun korporasi dapat dimintai tanggungjawab pidana apabila mengenai pemungutan iuran yang tidak berjalan sesuai dengan penahapan yang telah ditentukan terhadap peserta BPJS.
\end{abstract}

Kata Kunci : Pertanggung Jawaban Pidana, Korporasi, Undang-Undang BPJS

\section{PENDAHULUAN}

\subsection{Latar Belakang}

Korporasi merupakan perikatan beberapa orang yang bersepakat dengan tujuan untuk mencari keuntungan dan diakui keberadaannya secara hukum (badan hukum). Korporasi sebagai subyek hukum pidana dapat dipersamakan dengan manusia, karena di dalamnya terdapat hak dan kewajiban yang diberikan oleh hukum.

Hal ini menegaskan bahwa pernyataan terhadap seseorang telah melanggar hukum pidana dan dikenakan sanksi harus memenuhi dua syarat pokok:

a) Orang tersebut terbukti secara sah dan meyakinkan bahwa ia benar-benar telah melakukan suatu tindak pidana,

1 Mahrus Ali, asas-asas hukum pidana korporasi. Cet 2 Jakarta rajawali pers, 2015.,hlm 229 b) harus dibuktikan bahwa ia benar-benar merupakan orang yang dapat di pertanggung jawabkan secara pidana.

Pada tahap pertama ini yang dipandang sebagai pelaku tindak pidana adalah:

manusia alamiah ( natuurlijke persoon ). Pandangan ini dianut oleh KUHP yang sekarang berlaku di Indonesia. Pandangan ini dipengaruhi oleh asas, societas delinquere non potest ' yaitu badan hukum tidak dapat melakukan tindak pidana. Apabila dalam suatu perkumpulan terjadi tindak pidana maka tindak pidana tersebut dianggap dilakukan oleh pengurus korporasi tersebut. Pandangan ini merupakan dasar bagi pembentukan Pasal 59 KUHP.yang menyatakan 'Dalam hal-hal di mana karena ditentukan pidana terhadap pengurus, anggota-anggota badan pengurus atau komisaris-komisaris, maka pengurus, anggota badan pengurus atau komisaris yang 
ternyata tidak ikut campur melakukan pelanggaran tidak dipidana.

Pada tahap kedua ini korporasi diakui dapat melakukan tindak pidana, akan tetapi yang dapat dipertanggungjawabkan secara pidana, adalah para pengurusnya yang secara nyata memimpin korporasi tersebut, dan hal ini dinyatakan secara tegas dalam peraturan perundang-undangan yang mengatur tentang hal tersebut.

Pada tahap ketiga ini dibuka kemungkinan untuk menuntut korporasi dan meminta pertanggungjawabannya menurut hukum pidana. Alasan menuntut pertanggungjawaban pidana terhadap korporasi ini antara lain karena dalam delikdelik ekonomi dan fiskal, keuntungan yang diperoleh korporasi atau kerugian yang diderita masyarakat, dapat demikian besarnya, sehingga tak akan mungkin seimbang bilamana pidana hanya dijatuhkan kepada pengurus korporasi saja. Juga diajukan alasan bahwa dengan hanya memidana para pengurus tidak atau belum ada jaminan bahwa korporasi tidak akan mengulang delik tersebut. Dengan memidana korporasi dengan jenis dan beratnya yang sesuai dengan sifat korporasi itu, diharapkan dapat dipaksa korporasi untuk mentaati peraturan yang bersangkutan.

Permasalahan tersebut dilatarbelakangi dengan masih banyaknya korporasi pemberi kerja yang berdalih tidak mengetahui adanya kewajiban kepesertaan yang ditentukan oleh peraturan perundang-undangan yang berlaku saat ini. Dalam Undang-undang Nomor 24 Tahun 2011 tentang Badan Penyelenggaraan Jaminan Sosial mengatur tentang kewajiban pemberi kerja selain penyelenggara negara untuk mendaftarkan dirinya dan pekerjanya sesuai dengan program jaminan sosial yang diikuti melalui beberapa penahapan yang ditentukan dalam Peraturan Pemerintah. Namun pengaturan korporasi pada Undangundang Nomor 24 Tahun 2011 tersebut tidak ada menjelaskan mengenai tanggungjawab pidana yang dapat dijatuhkan kepada korporasi apabila ia tidak melaksanakan kewajibannya dalam urusan kepesertaan tersebut. Hal demikian yang dapat menyebabkan terjadinya kekosongan hukum.

\subsection{Perumusan Masalah}

Berdasarkan latar belakang yang telah diuraikan, dapat dirumuskan permasalahan dalam penelitian ini sebagai berikut:

1. Bagaimana bentuk petanggungjawaban tidak pidana korporasi terhadap pemberi kerja yang tidak mendaftarkan pekerjanya menjadi peserta badan penyelenggaraan jaminan sosial

2. Bagaimana mekanisme penerapan sanksi terhadap korporasi yang melakukan tindak pidana dalam Undang-Undang Nomor 24 Tahun 2011 tentang Badan Penyelenggara Jaminan Sosial.

\section{TINJAUAN PUSTAKA}

\subsection{Pengertian Korporasi}

Korporasi merupakan perikatan beberapa orang yang bersepakat dengan tujuan untuk mencari keuntungan dan diakui keberadaannya secara hukum (badan hukum). Korporasi sebagai subyek hukum pidana dapat dipersamakan dengan manusia, karena di dalamnya terdapat hak dan kewajiban yang diberikan oleh hukum.

Jika menurut hukum pidana korporasi tidak sama pengertiannya dengan hukum 
perdata. Pengertian korporasi menurut hukum pidana lebih luas berbeda dengan pengertian menurut hukum perdata. Menurut hukum perdata subyek hukum, yaitu yang dapat atau berwenang melakukan perbuatan dalam bidang hukum perdata. Misalnya membuat perjanjian, terdiri atas dua jenis, yaitu orang perseorangan dan badan hukum.

Beberapa pengertian lain tentang korporasi yang dapat penulis kemukakan disini antara lain seperti pendapat yang disampaikan oleh andi zainal abidin farid yang mengemukankan bahwa korporasi di pandang sebagai realita sekumpulan manusia yang diberikan hak oleh yunit hukum, yang di berikan pribadi hukum untuk tujuan tertentu.

Sedangkan menurut sebekti dan tjitro sudiro mengatakan bahwa yang dimaksud dengan korporasi adalah suatu perseroan yang merupakan badan hukum senada dengan pendapat tersebut diatas, sebagaimana di kemukakan oleh utrech dan M.soleh djindang mengemukakan bahwa korporasi adalah suatu gabungan orang dalam pergaulan hukum bertindak bersama sama sebagai suatu subyek hukum tersendiri sebagai suatu personafikasi.

\subsection{Kewajiban Korporasi}

Pemberi kerja secara bertahap wajib mendaftarkan dirinya dan pekerjanya sebagai peserta kepada BPJS, sesuai dengan program jaminan sosial yang diikuti dan pekerja berhak untuk mendaftarkan diri sebagai peserta program jaminan sosial atas tanggungan pemberi kerja apabila pemberi kerja telah nyata-nyata tidak mendaftarkan pekerjanya pada BPJS.

a. Pengusaha yang mempekerjakan tenaga kerja sebanyak 10 orang atau lebih, atau

membayar upah paling sedikit Rp 1 juta sebulan, wajib mengikutsertakan tenaga kerjanya dalam program jaminan sosial tenaga kerja.

Adapun sanksi jika perusahaan selain penyelenggara negara tidak melaksanakan kewajiban mendaftarkan pekerjanya sebagai Peserta kepada BPJS adalah sanksi administratif. Sanksi administratif itu dapat berupa: ${ }^{2}$

a. teguran tertulis;

b. denda; dan/atau

c. tidak mendapat pelayanan publik.

\subsection{Perlindungan Hukum Bagi Pekerja}

Perlindungan tenaga kerja bertujuan untuk menjamin berlangsungnya hubungan kerja. Untuk melindungi tenaga kerja akhirnya Pemerintah Indonesia membuat UndangUndang No. 24 tahun 2011 tentang BPJS Ketenagakerjaan. Sebagai perpanjangan tangan pemerintah BPJS Ketenagakerjaan telah bekerja melayani para pekerja dengan baik namun banyaknya perusahaan yang mempunyai tenaga kerja terkadang belum mendaftarkan pekerjanya kedalam BPJS Ketenagakerjaan. Hal ini membuat para tenaga kerja belum terlindungi kesehatan dan keselamatannya saat bekerja.

Setiap pekerja tentu memiliki hak untuk mendapatkan imbalan, serta perlakuan yang adil dan layak dalam hubungan kerja. Termasuk dalam jaminan sosial, seperti jaminan kecelakaan kerja (JKK), jaminan hari tua (JHT), jaminan kematian (JK), dan

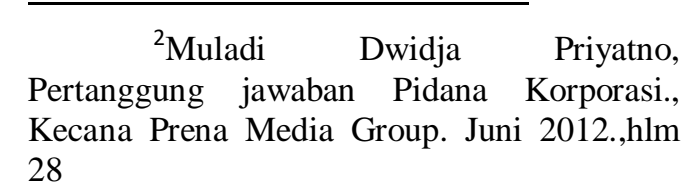


jaminan pensiun, jaminan yang dimaksud sudah termasuk pada program yang dibentuk oleh Badan Penyelenggara Jaminan Sosial (BPJS) Ketenagakerjaan. Dalam BPJS ini hakikatnya ialah perlindungan tenaga kerja dan dunia usaha.

\section{METODE PENELITIAN}

\subsection{Tipe Penelitian}

Penelitian ini menggunakan metode penelitian hukum normatif. Penelitian hukum normatif atau penelitian hukum kepustakaan adalah penelitian hukum yang dilakukan dengan meneliti bahan pustaka atau data sekunder belaka.

\subsection{Sumber Bahan Hukum}

Penelitian ini menggunakan jenis data sekunder yang meliputi:

a) Bahan hukum primer

Bahan hukum primer yang digunakan terdiri dari peraturan perundang-undangan, catatan resmi, risalah dalam pembuatan perundang-undangan dan putusan hakim. Penelitian ini menggunakan sumber bahan hukum primer yaitu Undang-Undang Nomor 24 tahun 2011 tentang badan penyelenggaraan jaminan sosial (BPJS), Peraturan Pemerintah Republik Indonesia Nomor 14 Tahun 1993 Tetang Penyelenggaraan Program JaminanSosial Tenaga Kerja, Peraturan Presiden Republik Indonesia Nomor 109 Tahun 2013 Tentang Penahapan Kepesertaan Program Jaminan Sosial.

Bahan hukum sekunder

b) Bahan hukum sekunder yang utama adalah buku teks karena buku teks berisi mengenai prinsip-prinsip dasar ilmu hukum dan pandangan-pandangan klasik para sarjana yang mempunyai kualifikasi tinggi. Bahan hukum skunder yang digunakan yaitu jurnal dan artikel ilmiah.

c) Bahan hukum tersier

Bahan hukum tersier yakni bahan yang memberikan petunjuk maupun penjelasan terhadap bahan hukum primer dan sekunder, contohnya adalah kamus, ensiklopedia, indeks kumulatif, dan seterusnya. Dalam penelitian ini menggunakan bahan hukum tersier berupa kamus hukum, kamus besar bahasa Indonesia, dan lain-lain sebagai penunjang.

\subsection{Analisis Bahan Hukum}

Penelitian ini menggunakan teknik penelitian deskriptif. Setelah semua data yang dibutuhkan terkumpul, langkah selanjutnya menginventarisasi data yang diperoleh. Hasil inventarisasi data diuraikan dalam bentuk kalimat yang baik dan benar, dianalisis, dan diinterpretasikan dengan peraturan perundangundangan yang berlaku terkait dengan korporasi dan undang-undang jaminan sosial.

\section{HASIL DAN PEMBAHASAN}

A. Bentuk Petanggungjawaban Tidak Pidana Korporasi Terhadap Pemberi Kerja Yang Tidak Mendaftarkan Pekerjanya Menjadi Peserta Badan Penyelenggaraan Jaminan Sosial

Mengenai kedudukan sebagai pembuat terdapat bentuk pertanggung jawaban korporasi, sebagai berikut: ${ }^{3}$

${ }^{3}$ DwidjaPriyatno,SistemPertanggung jawaban Pidana Korporasi.Cet 1, Kecana Prena Media Group. Oktober 2017.,hlm 134 
a) Pengurus korporasi sebagai pembuat dan penguruslah yang bertanggunglah yang bertanggung jawab .

b) Korporasi sebagai pembuat dan pengurus bertanggungjawab.

c) Korporasi sebagai pembuat dan juga sebagai yang bertanggungjawab.

Pertanggungjawaban korporasi dalam hukum pidana muncul tidak melalui penelitian yang mendalam dari para ahli tapi sebagai akibat dari kecenderungan dari formalisme hukum (legal formalism). Doktrin pertanggungjawaban pidana korporasi telah berkembang tanpa ada teori perkembangannya melalui peran pengadilan. Penerimaan korporasi sebagai subyek hukum layak nya manusia melauli peran pengadilan. Hakim di dalam sistem common law melakukan suatu analogi atas subyek hukum manusia

Para hakim pada waktu itu tidak memiliki banyak teori untuk membebankan tidakan korporasi melain kan memberikan suatu pertanyaan apakah suatu korporasi dengan entitas hukum tanpa memiliki bentuk pesiis yang jelas dapat juga di persyaratkan memiliki kondisi/keadaan pesikologis agar bisa dikakukan suatu penuntutan kepada korporasi yang melanggar hukum. berdasarkan pemikiran ini akhirnya disepakati bahwa korporasi juga dianggap sebagai subyek hukum yang bertanggungjawab pada kejahatan-kejahatan ringan. Setelah berjalannya waktu molai lah muncul tori teori baru antara lain:

1) Direct Corporate Criminal Liability

2) Strict Liability

3) Vicarius liability

4) Aggregasi

5) Corporate Culture Model
Teori direct corporate criminal liability (pertanggun gjawaban pidana secara langsung). Menurut teori ini korporasi bias melakukan sejumlah delik secara langsung melalui orang-orang yang sangat berhubungan erat dengan korporasi dan di pandang sebagai perusahaan itu sendiri. Dalam keadaan ini mereka tidak di anggap sebagai pengganti oleh karena itu pertanggung jawaban korporasi tidak bersifat pertanggung jawaban pribadi/perseorangan.

Tori Strict Liability (pertanggung jawaban tanpa adanya kesalahan) teori ini dapat di artikan sebagai tiada pidana tanpa kesalahan subjektif atau kesalahan tanpa dapat dicela. Akan tetapi dalam hukum pidana, ornag tidak dapat berbicara tentang kesalahan tanpa adanya perbuatan tidak patut. Karena itu asas kesalahan diartikan sebagai tiada pidana tanpa perbuatan tidak patut yang objektif, yang dapat di celakan kepada pelakunya. Asas kesalahan adalah asas yang fundamental dalam hukum pidana, demikian fundamentalnya sehingga meresap dan menggema dalam gampir semua ajaran dalam hukum pidana.

Teori vacarius liability (tanggung jawab pidana pengganti) merupakan suatu doktrin untuk menyeimbangkan sekaligus untuk melengkapi asas tiada pidana tanpa kesalahan strict liability. Barda Nawawi Arief berpendapat bahwa vacarius liability adalah suatu konsep pertanggungjawaban seseorang atas kesalahan yang dilakukan orang lain seperti tindakan seseorang yang di lakukan di dalam ruang lingkup pekerjaannya.

Teori Agregasi dalam berbagai kasus, seringkali ditemukan bahwa aktifitas korporasi merupakan hasil dari usaha-usaha kolektif 
beberapa atau bahkan banyak agen. Berdasarkan teori ini, pertanggungjawaban korporasi didasarkan pada penjumlahan dari pikiran atau kesalahan dari individu yang mewakili korporasi. Agregasi disini berarti tidak benar-benar menjumlahkan semua pikiran, tetapi lebih membandingkan pikiran satu orang dengan orang lain. ${ }^{4}$

Teori Corporate Culture Model (sikap yang ada didalam tubuh pada umumnya di mana kegiatan relevan sedang berlangsung). Reformasi tanggungjawab pidana korporasi Australia dengan mengadopsi teori ini mengetengahkan kemungkinan bagi perubahan legislatif kepada cara di mana antribusi tanggungjawab pidana pada korporasi berkembang melalui keputusan pengadilan.

Dari penjalasan teori diatas yang cocok jika di terapkan dengan pertanggungjawaban korporasi dalam undang-undang no 24 tahun 2011 ialah teori Strict Liability dan Varariius Liabilitiy karena teori Strict Liability ini mengandung makna bahwa tanpa adanya kesalahan maka korporasi dapat di tuntut di muka hakim dan teori Varariius Liabilitiy sebagai pertanggungjawaban pengganti dan penguat teori Strict Liability.

Maka korporasi yang melanggar undang-undang BPJS yaitu lalainya korporasi yang tidak mendaftarkan pekerja untuk mendapatkan jaminan sosial akan dapat di pidana.
A. Mekanisme Penerapan Sanksi Terhadap Korporasi Yang Melakukan

Tindak Pidana Dalam Undang-

Undang Nomor 24 Tahun 2011

Tentang Badan Penyelenggara

Jaminan Sosial.

Peraturan Pemerintah Nomor 86 Tahun 2013 mengatur tata cara pengenaan sanksi administratif lebih lanjut yaitu Pemerintah, pemerintah daerah provinsi, atau pemerintah daerah kabupaten/kota dalam melaksanakan pengenaan sanksi tidak mendapat pelayanan publik tertentu kepada:

a. Pemberi Kerja Selain Penyelenggara Negara yang melanggar ketentuan sebagaimana dimaksud dalam Pasal 3 ayat (1) huruf a dan setiap orang, selain pemberi kerja, Pekerja, dan penerima bantuan iuran yang melanggar ketentuan sebagaimana dimaksud dalam Pasal 4 ayat (1) huruf a dilakukan dengan mempersyaratkan kepada mereka untuk melengkapi identitas kepesertaan jaminan sosial dalam mendapat pelayanan publik tertentu; dan

b. Pemberi Kerja Selain Penyelenggara Negara yang melanggar ketentuan sebagaimana dimaksud dalam Pasal 3 ayat (1) huruf b dan setiap orang, selain pemberi kerja, Pekerja, dan penerima bantuan iuran yang melanggar ketentuan sebagaimana dimaksud dalam Pasal 4 ayat (1) huruf b dilakukan setelah mendapat surat permohonan pengenaan sanksi dari BPJS.

${ }^{4}$ Moeljatno., asas-asas hukum pidana . Cet 9 Jakarta Rineka Cipta, 2015.,hlm 220 
Sanksi tidak mendapat pelayanan publik tertentu yang dikenai kepada Pemberi Kerja Selain Penyelenggara Negara meliputi: ${ }^{5}$

a. perizinan terkait usaha;

b. izin yang diperlukan dalam mengikuti tender proyek;

c. izin memperkerjakan tenaga kerja asing;

d. izin perusahaan penyedia jasa pekerja/buruh; atau

e. izin Mendirikan Bangunan (IMB).

Sanksi tidak mendapat pelayanan publik tertentu yang dikenai kepada setiap orang, selain pemberi kerja, Pekerja, dan penerima bantuan iuran yang memenuhi persyaratan kepesertaan dalam program jaminan sosial meliputi:Izin Mendirikan Bangunan (IMB)

a. Surat Izin Mengemudi (SIM);

b. sertifikat tanah;

c. paspor; atau

d. Surat Tanda Nomor Kendaraan (STNK).

Pengenaan sanksi tidak mendapat pelayanan publik tertentu dilakukan oleh unit pelayanan publik pada instansi Pemerintah, pemerintah daerah provinsi, atau pemerintah daerah kabupaten/kota.

Kemudian Perihal Tata Cara Pengenaan Sanksi Kepada Pemberi Kerja Selain Penyelenggara Negara diatur pula dalam Peraturan Pemerintah Nomor 86 Tahun 2013, antara lain.

1. Pemberi Kerja Selain Penyelenggara Negara yang melanggar ketentuan sebagaimana dimaksud dalam Pasal 3

${ }^{5}$ Zulkarnain., praktik pradilan pidana . Cet 3 Setara Press, juni 2016.,hlm 12 dalam peraturan pemerintah ini berkaitan dengan pemberi kerja atau korporasi yang tidak mendaftarkan dirinya dan pekerjanya serta tidak memberikan data diri dan pekerja kepada BPJS dikenai teguran tertulis pertama untuk jangka waktu paling lama 10 (sepuluh) hari oleh BPJS.

2. Apabila sampai dengan berakhirnya jangka waktu 10 (sepuluh) hari sanksi teguran tertulis pertama Pemberi Kerja Selain Penyelenggara Negara sebagaimana dimaksud pada poin 1 (satu) tidak melaksanakan kewajibannya, BPJS mengenakan sanksi teguran tertulis kedua untuk jangka waktu 10 (sepuluh) hari.

3. Sanksi denda dikenakan apabila setelah pengenaan sanksi teguran tertulis kedua berakhir Pemberi Kerja Selain Penyelenggara Negara tidak melaksanakan kewajibannya.

4. Denda dikenakan sebesar $0,1 \%$ (nol koma satu persen) setiap bulan dari iuran yang seharusnya dibayar yang dihitung sejak teguran tertulis kedua berakhir.

5. Denda disetorkan kepada BPJS bersamaan dengan pembayaran iuran bulan berikutnya.

6. Apabila sanksi berupa denda tidak disetor lunas, Pemberi Kerja Selain Penyelenggara Negara dikenai sanksi tidak mendapat pelayanan publik tertentu.

7. Sanksi tidak mendapat pelayanan publik tertentu dicabut apabila denda telah disetor secara lunas kepada BPJS dan telah mendaftarkan dirinya dan pekerjanya sebagai peserta kepada BPJS secara bertahap sesuai dengan program jaminan sosial yang diikutinya bagi Pemberi Kerja Selain Penyelenggara Negara yang 
melanggar kewajiban; atau telah memberikan data dirinya dan pekerjanya berikut anggota keluarganya kepada BPJS secara lengkap dan benar bagi Pemberi Kerja Selain Penyelenggara Negara yang melanggar kewajiban.

8. Bukti lunas pembayaran denda, pendaftaran kepesertaan, dan bukti pemberian data kepesertaan yang lengkap dan benar dijadikan sebagai dasar pencabutan sanksi tidak mendapat pelayanan publik tertentu.

Berkaitan dengan Mekanisme atau proses penerapan sanksi dan pemidanaan yang melanggar ketentuan dalam UndangUndang Nomor 24 Tahun 2011 tentang Badan Penyelenggara Jaminan Sosial yaitu. ${ }^{6}$

Mekanisme penerapan sanksi terhadap korporasi/pemberi kerja baik secara administratif maupun sanksi pidana belum berjalan. Dalam pengertiannya berdasarkan Peraturan Pemerintah No. 86 Tahun 2013 sanksi administratif diberikan bagi perusahaan yang tidak atau belum mendaftarkan pekerjanya ke dalam program BPJS Ketenagakerjaan maka dalam proses yang sudah dilakukan beberapa kali seperti imbauan dan teguran dan perusahaan tetap bandel atau tetap tidak merespon hal tersebut maka dalam hal ini BPJS Ketenagakerjaan merekomendasikan kepada Pemerintah

Daerah untuk perusahaan yang bandel itu tidak mendapatkan izin usaha, tidak mendapatkan pelayanan publik tertentu seperti Surat Izin Mengemudi (SIM), dan tidak dapat

${ }^{6}$ Sultan Remy., tindak pidana korporasi \& seluk-beluknya . Cet 1 Kencana, maret 2017.,hlm 5-6 mengurus Kartu tanda penduduk pada instansi yang bersangkutan bahkan hukuman terberat dari sanksi administratif perusahaan/korporasi tersebut bisa ditutup. Tapi peran BPJS Ketenagakerjaan masih sebatas merekomendasikan, sedangkan yang melaksanakan hal itu adalah Pemerintah Daerah sesuai dengan Peraturan Pemerintah.

\section{PENUTUP}

\section{A. Kesimpulan}

B. Korporasi merupakan badan hukum yang termasuk di dalam kategori "Pemberi Kerja" yang diatur dalam Ketentuan Umum Undang-Undang BPJS. Dengan demikian Korporasi adalah suatu Subjek yang dapat mempertanggung jawabkan perbuatannya, di dalam konteks peradilan korporasi dapat mewakili di peradilan.

C. Untuk peraturan pelaksana atau peraturan yang lebih teknis dari UndangUndang No. 24 Tahun 2011 yang mengatur mekanisme atau proses penerapan sanksi terutama sanksi Pidana belum ada, masih sebatas ketentuan lebih lanjut berkaitan dengan sanksi administratif dalam Peraturan Pemerintah No. 86 Tahun 2013. Sanksi Pidana sama sekali belum berjalan akan tetapi sanksi administratif sudah mulai dilakukan, namun dalam pelaksanaan sanksi administratif juga belum ada korporasi yang dikenakan sanksi yaitu tidak mendapat pelayanan publik tertentu dari pemerintah kepada perusahaan (pekerjanya). Berkaitan dengan belum adanya petunjuk teknis dari Undangundang BPJS dan PP No. 86 Tahun 
2013, maka prosesnya belum dapat diterapkan secara maksimal sebelum adanya aturan hukum yang lebih teknis, dan pada akhirnya eksekusinya masih gantung dan belum dapat diterapkan.

D. Saran

1. Perlu adanya sosisalisasi terhadap undang-undang No. 24 Tahun 2011 tentang badan penyelenggaraan jaminan sosial dan seharusnya BPJS perlu mengadakan survey ke perusahaan atau korporasi untuk mencegah perusahaan supaya menaati dan mengikutsertakan karyawan nya untuk mendapatkan jaminan sosial.

2. Perlu adanya pembenahan ulang terhadap undang-undang No. 24 Tahun 2011 tentang badan penyelenggaraan jaminan sosial, melakukan pembenahan yang lebih tegas agar korporsi tidak lagi melanggar aturang yang telah di tentukan.
Untuk itu perlu adanya aturan yang lebih khusus dan lebih teknis mengatur perihal mekanisme penerapan sanksi baik administratif maupun sanksi pidana.

\section{DAFTAR PUSTAKA}

Mahrus Ali, asas-asas hukum pidana korporasi. Cet 2 Jakarta rajawali pers, 2015.

Muladi Dwidja Priyatno, Pertanggungjawaban Pidana Korporasi., Kecana Prena Media Group. Juni 2012.

Dwidja Priyatno, Sistem Pertanggungjawaban Pidana Korporasi.Cet 1, Kecana Prena Media Group. Oktober 2017.

Moeljatno., asas-asas hukum pidana . Cet 9 Jakarta Rineka Cipta, 2015.

Zulkarnain., praktik pradilan pidana . Cet 3

Setara Press, juni 2016.

Sultan Remy., tindak pidana korporasi \& seluk-beluknya . Cet 1 Kencana, maret 2017 